\title{
The Influence of Good Corporate Governance Towards Financial Performance Using Earnings Management As the Intervening Variable at Banking Companies Listed in Indonesia's Stock Exchange
}

Riri Mayliza, Aminar Sutra Dewi, and Lola Fitria Sari

Sekolah Tinggi Ilmu Ekonomi KBP

\section{Abstract}

The increase of non-performing loan in banking industry causes the commodity prices falling and value change. This research is aimed at testing the influence of good corporate governance (board of directors and audit committee) towards financial performance by using earnings management as the intervening variable. The sample

Corresponding Author:

Riri Mayliza

ririmayliza6@gmail.com

Received: 18 January 2019

Accepted: 24 March 2019

Published: 31 March 2019

Publishing services provided by

Knowledge E

(c) Riri Mayliza et al. This article is distributed under the terms of the Creative Commons

Attribution License, which permits unrestricted use and redistribution provided that the original author and source are credited.

Selection and Peer-review under the responsibility of the First ELEHIC Conference Committee. of this research was 14 companies that are listed in Indonesia's stock exchange within 2012-2016. This research used regression analysis method by using intervening variable and path analysis for mediator variable. The research finding shows that board of directors have positive and significant impact towards financial performance, audit committee has positive and insignificant impact towards financial performance, board of directors has negative and insignificant impact towards earnings management, audit committee has negative and insignificant impact towards earnings management, and earnings management has positive but insignificant impact towards financial performance. At Sobel test, earnings management does not mediate the relationship between the board of directors and financial performance, and earnings management does not mediate audit committee and financial performance.

Keywords: board of directors, audit committee, earnings management, financial performance

\section{Introduction}

Financial performance is an indicator that can be used in knowing the financial condition of a company. The financial performance is made for measuring the healthiness of a company. Financial performance is a result of many of individual decisions made continuously by the management. The financial performance of banking industry has a vital role since a bank has direct relationship towards trustworthiness. In addition, the 
financial performance of banking will increase the sales value and the company's reputation. To decide the investment for financial performance, it always needs customers and investors. This financial performance has a significant role towards the decision.

Return on Asset (ROA) is a measurement of company's performance that shows the company's capability in producing the profit to make use of the company's assets. A financial report is a set of information issued by a company that is not separated from earnings management actions done by the company's manager in improving the company's reputation.

In 2017, the performance given by the banking sector was less than good so that this sector was still facing bad quality of assets. Bad quality of asset can be seen from the problem of non performing productive assets. It happens since the bank aggressively distributes the credit to the market so that bad credits or Non-Performing Loan (NPL) occurs and it becomes a special mention for a bank. Non-Perfoming Loan (NPL) and special mention that are listed in category 2 through 5 in the credit causes commodity prices falling and the effect of value change.

The performance of a company can be affected by the management system applied in the company. The form of this management is usually known as GCG or Good Corporate Governance. It is a thing that can be used by the user of the financial report in making decisions since the principle contained in GCG is transparency and accountability and presenting complete and qualified informatio GCG is related to investors' trustworthiness towards the managers whether they believe the managers are able to give profit to them for the funds or the investment that had been invested by the investors or not [1]. There are seven mechanisms in measuring corporate governance i.e. institutional ownership, managerial ownership, the board of commissioners, the board of directors, independent board of commissioner, the company size, and audit committee.

Director is an individual who plays an important role in determining the company's growth. The basic principle that should be met in order that the director's duties can be done smoothly and efficiently is the amount of the director who has to make decision effectively, accurately, fast and act independently [1]. The audit committee is defined as a committee who works independently and professionally. The audit committee is formed by the board of commissioners as the assistant or an individual who can strengthen the function of the board of commissioners and assisting the board of commissioners in conducting both the function of supervising and financial reporting; implementing Good Corporate Governance in a company and conducting audit activity and risk management in a company. 
The audit committee gives a viewpoint towards accounting problems, financial report and the description, internal supervision system and independent auditor. The responsibility of audit committee in general in the field of financial reporting is ensuring that the financial report has illustrated the common condition of a company in financial condition, surplus, and long-term commitment [2].

One of the purposes of GCG is decreasing earnings management actions or practices that are often done by the managers in a company. So, it is expected that by using supervision and controlling system as the basic principle of GCG can decrease earnings management actions or practices in the implementation of GCG especially for the implementation of the existing principles. Earnings management is measured by using accrual basis accounting method. This method is used for identifying earnings management by using cash and accrual component in the financial report [3]

\section{Agency Theory}

The perspective of the agency relationship is a basis to understand the corporate governance. It is because of the agency theory is the basic concept of corporate governance which has a function as a tool in convincing the investors that they will accept the return for the funds they have been invested. Corporate governance is a belief owned by the investors about the capability of the company in giving a profit to them. Besides that, the investors believe that the manager of the company will never embezzle or steal or even invest the funds that the investors had been invested to an unprofitable project and CG has also a relevance to how the investors control the manager of the company [4]

The analogy of agency theory is like between the owner of the company and the management of the company. The actions are done by some agencies; meanwhile, the function of utility in the final interest is the principal's ownership. The agency theory has strong relationship towards the important role of accountancy in providing information for decision making. This role is associated to stewardship role of accountancy where the agent reports the thing that happens to the principal [5]

The agency relationship happens when an individual or more that is usually known as a principal rents other individuals or other organizations, known as an agent, to provide services and to delegate the authorities in decision making towards the agent [1]. The relationship between the principal and the agent should be mutually beneficial for each other. However, the thing that is often happened is the problem of agency between the owner and the company's management. 


\section{Development Hypothesis}

\subsection{Board of directors and financial performance}

Board of directors in a company will determine the policy or short-term or long-term company's strategy that will be taken [6]. To make the implementation of director's tasks run effectively, one of the principles that should be met is the directors' composition as it is to allow an accurate, fast, and effective decision making and they can act independently [1]) The decision made by the manager is related to the financial performance of a company which of the decisions done, at the same time, we can see the company's performance.

A research done by[1] about the influence of GCG towards financial performance by using similar variable reveals that the board of directors has a positive and significant impact towards financial performance. Another research that has been done by[7] about measuring the influence of Corporate Governance (CG) mechanism and the ownership structure towards financial performance by using multiple linear regression as the instrument for the analysis reveals that the board of directors has an impact towards financial performance. Furthermore, a research done by [1] finds out that the board of directors and other proxies give positive impact simultaneously towards financial performance, but the board of directors has no significant impact towards financial performance partially.

$\mathrm{H}_{1}$ : It is assumed that the board of directors has a positive and significant impact towards financial performance.

\subsection{Audit committee and financial performance}

Based on Kep-315/BEJ/06200, the audit committee is formed by the board of commissioners from the listed companies. The member of the audit committee is appointed and is dismissed by the board of commissioners of the listed companies [1]. The audit committee is responsible for conducting supervision in increasing the effectiveness of creating the transparency and the activity of qualified financial reporting, the compliance towards the applicable laws and regulation, and sufficient internal supervision. The relevancy of audit committee and financial performance can be seen from the function of supervision done by the audit committee. The audit committee has an independent duty to ensure whether the financial report that has been made and compiled by the manager and the board of commissioners is clear and accountable or not. 
A research that has been done by [1] about the influence of Good Corporate Governance (GCG) as an indicator towards financial performance finds the analysis result that it can be seen partially from the t-values significantly. It is found out that audit committee has a positive but insignificant impact towards financial performance. A research done by [9] shows different result that the audit committee gives positive and significant impact towards financial performance. The financial report of a company will be more qualified by the existence of audit committee in a company related to their duties and responsibilities in supervising the financial report.

$\mathrm{H}_{2}$ : It is assumed that the audit committee has a positive but insignificant impact towards financial performance.

\subsection{Board of directors and earnings management}

In general, earnings management is defined as the attempt done by the company's manager in intervening or affecting the information inside the financial report. The attempt is done to deceive the stakeholder who wants to know about the financial performance and the company's condition. The board of directors is an organization that determines the kind of policy that will be taken by the company or the kind of strategy both shortterm period and long-term period that will be applied.

A research done by [10] shows that the board of directors has a positive impact towards earnings management. Further, a research that has been done by [8] about corporate governance as a tool for reducing the earnings management practices shows that the amount of board of directors partially has a positive and significant impact towards earnings management.

$\mathrm{H}_{3}$ : It is assumed that the board of directors has a positive and significant impact towards earnings management.

\subsection{Audit committee and earnings management}

The mechanism of good corporate governance (institutional ownership, managerial ownership, the proportion of board of commissioners and audit committee) has a capability in producing some profits. By applying good corporate governance, it is expected that it can decrease the motivation of the manager in doing manipulation so that the performance that is being reported reflects the individual's economic condition. 
[6] has done a research about the influence of audit committee independence towards earnings management. The result of the analysis finds that the audit committee has a negative impact toward earnings management. Furthermore, a research that has been done by [11] obtains a result that the audit committee has no significant impact towards earnings management.

$\mathrm{H}_{4}$ : It is assumed that the audit committee has a negative and insignificant impact towards earnings management.

\subsection{Earnings management and financial performance}

Profit is a measuring instrument used by the company's management in measuring the management's performance within a certain period. It becomes the main concern for the stakeholders in estimating the management's performance and the responsibility for managing the resources that have been given to the management. The profit is also used for estimating the future prospect [8]

A research that has been done [4], shows that earnings management has no significant impact towards financial performance. This finding is also supported by a research done by [11] about the mechanism of good corporate governance, earnings management, and financial performance by using Manufacturer Company listed in Indonesia's Stock Exchange as the object. It is found that earnings management has a negative and insignificant impact towards financial performance.

$\mathrm{H}_{5}$ : It is assumed that earnings management has a negative and insignificant impact towards financial performance.

\subsection{Board of directors, earnings management and financial perfor- mance}

Good corporate governance is proposed and it is expected to be able in giving some improvement towards the company's performance through monitoring the management's performance and it is expected to guarantee the accountability of management towards the stakeholders by according to the applicable regulatory framework. The relevant parties who have certain intention will compile the financial report according to their willingness. It frequently happens and it is considered as a common thing in managing a company. It happens since the supervision done by the company is still less than optimal and the implementation of regulation and accounting standard, auditing, 
and the principle of transparency is still weak. Therefore, good supervision and good control need to be applied to avoid the corruption actions. So, an individual who has a role in controlling and supervising the actions and decisions made by the manager is needed to achieve healthy, clean and accountable company.

A research that has been done by [4] about good corporate governance, earnings management, and financial performance reveals that the GCG variables are tested and it has a significant impact towards earnings management simultaneously. Meanwhile, in the next test, earnings management has no impact towards financial performance.

$\mathrm{H}_{6}$ : It is assumed that earnings management mediates the relationship between the board of directors and financial performance.

\subsection{Audit committee, earnings management, financial performance}

The application of GCG principle makes the company will have an audit committee and independent commissioner as an individual who conducts supervision and controlling activities in creating justice, transparency, accountability, and responsibility. The proportion of independent audit committee has a positive relationship between the audit committee and the reduced manager's pressure towards audit committee in compiling the financial report. In addition, the competency of the audit committee has to do with the weakening of possible actions in earnings management. It means that the more competent of the audit committee, the less possibility of earnings management activity [8]

A research that has been done by [4] about good corporate governance mechanism, earnings management and financial performance that uses audit committee as one of the variables in the research. The finding of the research reveals that audit committee gives positive but insignificant impact towards earnings management and earnings management has a negative and insignificant impact towards financial performance.

$\mathrm{H}_{7}$ : Earnings management mediates the relationship between the audit committee and financial performance.

\section{Research Method}




\subsection{Data and sample}

The type of this research was quantitative research which was based on a numerical basis. The object of this research was banking companies listed in Indonesia's stock exchange. Meanwhile, the population in this research was all banking companies listed in Indonesia's stock exchange within 2012-2016 for about 40 companies. The sampling technique used here was purposive sampling technique. From the sampling technique, it had been collected 14 banking companies which fulfilled all criteria as the samples. The type of the data in this research was quantitative data that was based on secondary data in form of a financial report from sample companies issued on the website of Indonesia's stock exchange, i.e. www.idx.co.id.

\subsection{Operational definition of variables}

\begin{tabular}{|c|c|c|}
\hline Variables & Definitions & Proxy (Indicators) \\
\hline Borad of Directors & $\begin{array}{l}\text { Board of directors is a member who takes responsibility } \\
\text { for the company's performance and the company's } \\
\text { management. }\end{array}$ & $\begin{array}{l}\text { The whole member of } \\
\text { board of directors in a } \\
\text { company }\end{array}$ \\
\hline Audit Committee & $\begin{array}{l}\text { Audit committee takes responsibility for supervising the } \\
\text { financial report, external audit, internal controlling } \\
\text { system, and decreasing the opportunistic management } \\
\text { who conducts earnings management. }\end{array}$ & $\begin{array}{l}\text { The whole member of } \\
\text { audit committee in a } \\
\text { company }\end{array}$ \\
\hline $\begin{array}{l}\text { Financial } \\
\text { Performance }\end{array}$ & $\begin{array}{l}\text { The financial performance is a measuring instrument in } \\
\text { finding out the capability of the company. The financial } \\
\text { performance is measured using a ratio of Return on } \\
\text { Assets (ROA). ROA is a ratio used for measuring the } \\
\text { bank management's capability in obtaining profit as a } \\
\text { whole and showing the performance efficiency level. }\end{array}$ & ROA $=\frac{\text { Net profit }}{\text { Total Assets }}$ \\
\hline $\begin{array}{l}\text { Earnings } \\
\text { Management }\end{array}$ & $\begin{array}{l}\text { Earnings management can be measured by using } \\
\text { accrual basis accounting model. This model uses cash } \\
\text { and accrual component in a financial report. }\end{array}$ & $\mathrm{TAC}_{t}=\mathrm{NI}_{t}-\mathrm{CFO}_{t}$ \\
\hline
\end{tabular}

\subsection{Data analysis technique}

\subsubsection{Descriptive statistics analysis}

Descriptive statistics had a function for giving illustration or description of the object that would be analyzed through data or samples and analysis and conclusion was not 
made for the public [4] Descriptive statistics in this research illustrated the mean scores, maximum and minimum score and also the standard deviation from sample data.

\subsubsection{Classic assumption test}

Classic assumption test used here consisted of three tests i.e. normality test that had a function to know whether the data had been used was already in normal distribution, multicollinearity test had a function to see if there was a correlation among independent variables, and heteroscedasticity test had a function to see if there was variance dissimilarity from the residual of one observation to another observation [4].

\subsubsection{Regression analysis using intervening variable}

Regression analysis was used for estimating the condition of the dependent variable that was affected by the independent variable. In conducting regression analysis by using an intervening variable, it had been used two regression models. The equations (models) used in this research were:

Multiple Regression Analysis:

$$
\begin{aligned}
& L N_{M L}=\alpha+\beta 1 L N_{D D}+\beta 2 L N_{K A}+e \\
& K K=\alpha+\beta 1 D D+\beta 2 K A+\beta 3 M L+e
\end{aligned}
$$

Description:

$$
\begin{aligned}
& K K=\text { Financial Performance } \\
& M L=\text { Earnings Management (Mediator) } \\
& \alpha=\text { polynomial constant } \\
& \beta=\text { Regression Coefficient } \\
& D D=\text { The amount of Board of Directors } \\
& K A=\text { The amount of Audit Committee } \\
& \text { Ln }=\text { Natural Logarithm } \\
& \text { e = Error }
\end{aligned}
$$




\subsubsection{Path analysis}

Path analysis was used to test the influence of intervening variable. A path diagram would be made in this path analysis to illustrate direct and indirect influence through intervening variable.

\subsubsection{Hypothesis testing}

1. T-test, the test was used to know the effect of independent variable towards dependent variable partially.

2. Sobel test, this test was used in conducting hypothesis testing for mediation effects. The test was done by testing the potency of indirect influence from independent variable to the dependent variable through mediator variable.

\section{Result and Discussion}

\subsection{Descriptive statistics analysis}

Descriptive statistics analysis was done to give an illustration or a description on research variables such as the amount of sample $(\mathrm{N})$, lowest score (minimum), highest score (maximum), mean score of the sample (mean) and the standard deviation of each variable.

TABLE 1: Statistical Description of Research Variable.

\begin{tabular}{|l|c|c|c|c|c|}
\hline Variables & N & Mean & Maximum & Minimum & $\begin{array}{c}\text { Standard } \\
\text { Deviation }\end{array}$ \\
\hline Board of Directors & 70 & 8.5143 & 12.00 & 4.00 & 2.30150 \\
\hline Audit Committee & 70 & 4.0857 & 8.00 & 3.00 & 1.29372 \\
\hline Financial Performance & 70 & 1.0429 & 3.00 & 0.00 & .89176 \\
\hline Earnings Management & 70 & -22.6692 & 800.84 & -857.93 & 255.91137 \\
\hline Source: Processed data & & & & & \\
\hline
\end{tabular}

The mean score of the board of directors, the audit committee, financial performance, and earnings management can be seen in the table above. The minimum score and the maximum score in a whole from each variable can also be seen in the table presented above. The standard deviation from each variable was also presented in Table 1. 


\subsection{Classic assumption test}

\subsubsection{Normality test}

Normality test was used to see whether the data used for the test had already in normal distribution or not by using more than $5 \%$ of significance level.

TABLE 2: The Result of Normality Test.

\begin{tabular}{l|c|c|} 
& \multicolumn{1}{c|}{$\begin{array}{c}\text { Asymp. Sig. } \\
\text { (2-tailed) }\end{array}$} & Description \\
\hline $\mathrm{DD}, \mathrm{KA} \rightarrow \mathrm{ML}$ & 0.740 & Normal Distribution \\
\hline $\mathrm{DD}, \mathrm{KA}, \mathrm{ML} \rightarrow \mathrm{KK}$ & 0.857 & Normal Distribution \\
\hline Source: Processed data & & \\
\hline
\end{tabular}

From the table about normality presented above, we can see the whole analyzed data was in normal distribution since the significance value was more than $5 \%$ or 0.05 .

\subsubsection{Multicollinearity test}

Multicollinearity test was used to see if there was a correlation between the independent variables. The level of decision making in this test could be seen from the VIF score which was less than 10.

TABLE 3: The Result of Multicollinearity Test.

\begin{tabular}{|c|c|c|c|c|}
\hline \multirow[t]{2}{*}{ Model } & & \multicolumn{2}{|c|}{ Collinearity Statistics } & \multirow{2}{*}{ Description } \\
\hline & & Tolerance & VIF & \\
\hline \multirow[t]{2}{*}{$\mathrm{DD}, \mathrm{KA} \rightarrow \mathrm{ML}$} & Board of Directors & 0.779 & 1.284 & Multicollinearity Free \\
\hline & Audit Committee & 0.779 & 1.284 & \\
\hline \multirow[t]{3}{*}{$\mathrm{DD}, \mathrm{KA}, \mathrm{ML} \rightarrow \mathrm{KK}$} & Board of Directors & 0.812 & 1.231 & Multicollinearity Free \\
\hline & Audit Committee & 0.829 & 1.206 & \\
\hline & Earnings Management & 0.978 & 1.023 & \\
\hline
\end{tabular}

From the table of multicollinearity above, it shows that all independent variables were free from multicollinearity symptom. It means that there was no correlation between those independent variables. 


\subsubsection{Heteroscedasticity test}

Heteroscedasticity test was used to know if there was variance dissimilarity from the residual of one observation to another observation.

TABLE 4: The Result of Heteroscedasticity Test.

\begin{tabular}{l|l|l|l}
\hline Model & & Sig & \multicolumn{1}{c}{ Description } \\
\hline $\mathrm{DD}, \mathrm{KA} \rightarrow \mathrm{ML}$ & Board of Directors & 0.134 & Heteroscedasticity Free \\
\hline & Audit Committee & 0.606 & \\
\hline $\mathrm{DD}, \mathrm{KA}, \mathrm{ML} \rightarrow \mathrm{KK}$ & Board of Directors & 0.057 & Heteroscedasticity Free \\
\hline & Audit Committee & 0.611 & \\
\hline & Earnings Management & 0.860 & \\
\hline Source: Processed data & &
\end{tabular}

In Table 4 above, it can be seen that the two tests for each independent variable were free from heteroscedasticity symptom. It can be known from the significance score resulted from Glejser test that was more than 0.05 .

\subsection{Regression analysis using intervening variable}

TABLE 5: The Result of Regression Analysis Model I.

\begin{tabular}{|c|c|c|c|c|c|}
\hline \multirow[t]{2}{*}{ Model } & \multicolumn{2}{|c|}{ Unstandardized Coefficients } & \multirow{2}{*}{$\begin{array}{c}\text { Standardized } \\
\text { Coeficients } \\
\text { Beta }\end{array}$} & \multirow[t]{2}{*}{$\mathrm{t}$} & \multirow[t]{2}{*}{ Sig } \\
\hline & B & Std. Error & & & \\
\hline (Constant) & 7.967 & 2.149 & & 3.708 & .001 \\
\hline Board of Directors & -2.025 & 1.095 & -.338 & -1.849 & .073 \\
\hline Audit Committee & -.442 & 1.200 & -.067 & -.368 & .715 \\
\hline
\end{tabular}

The table above was the result of multiple regression analysis model I. The board of directors had a regression coefficient of -0.338 . It shows that the increasing number of board of directors of 1 person causes earnings management having a decrease number of $33.8 \%$. The regression coefficient of audit committee resulted from this analysis was -0.067. It shows that the increasing number of the audit committee of 1 person makes earnings management has a decrease number of $6.7 \%$ by considering that other variables were constant. 
TABLE 6: The Result of Regression Analysis Model II.

\begin{tabular}{l|c|c|c|c|c|}
\hline & \multicolumn{2}{|c|}{ Non-standardized Coefficients } & $\begin{array}{c}\text { Standardized } \\
\text { Coefficients }\end{array}$ & $\mathrm{t}$ & Sig \\
\hline & $\mathrm{B}$ & Std. Error & Beta & \\
\hline (Constant) & -.870 & .399 & & -2.182 & .033 \\
\hline Board of Directors & .163 & .045 & .420 & 3.615 & .001 \\
\hline Audit Committee & .129 & .079 & .187 & 1.630 & .108 \\
\hline Earnings & 3.304 & .000 & .001 & .009 & .993 \\
\hline Management & & & & & \\
\hline Dependent Variable: Financial Performance & & & \\
\hline Source: SPSS Data & &
\end{tabular}

The table above was the result of multiple regression analysis of model II. The result from this regression analysis was the regression coefficient of the board of directors of 0.420 showed the increasing amount of board of directors that was 1 person. So, the financial performance would have an increasing number of $42 \%$. Meanwhile, the regression coefficient on the variable of the audit committee of 0.187 showed the increasing number of the audit committee of 1 person. It had a meaning that the financial performance would have an increasing number of $18.7 \%$. The regression coefficient for the variable of earnings management was 0.001 . It shows that the increasing number of earnings management actions of $1 \%$ causes the financial performance having an increasing number of $0.1 \%$.

\subsection{Path analysis}

Path analysis was used for testing the effect of the intervening variable (mediator). The path analysis is an extension of regression analysis for estimating indirect relationship among one variable through mediator variable. From the scores resulted from the two models of regression that had been done, it was obtained a path diagram as follows:

From the path diagram, it can be seen that each variable gave direct influence towards the variable of financial performance. The 0.420 was the direct influence given by the board of directors towards financial performance and 0.187 was the direct influence of audit committee towards financial performance. Meanwhile, the indirect influence was obtained by multiplying the direct influence between the board of directors and earnings management to the direct influence between earnings management and financial performance and vice versa. 


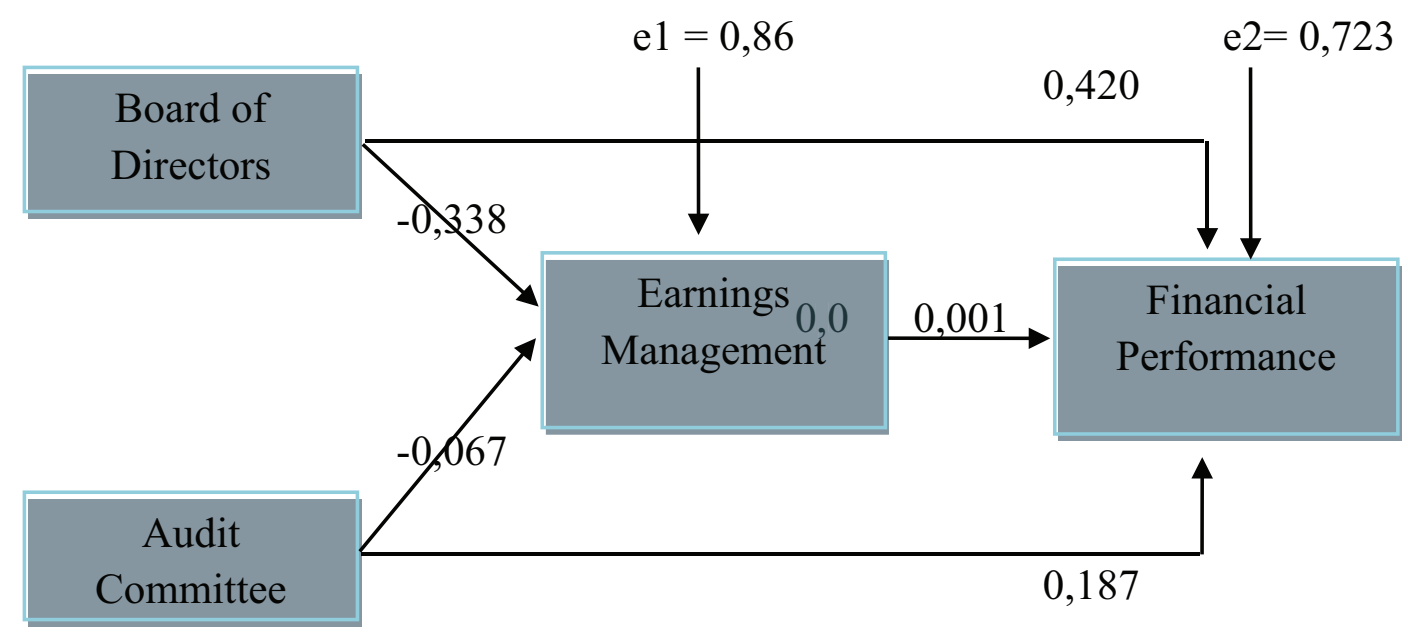

Figure 1: The Path Diagram of Model.

\subsection{Hypothesis testing}

\subsubsection{T-test (Partial)}

From the table of regression analysis of model I, it can be seen that the t-values resulted from the board of directors was -1.849 with 0.073 for significance score and it was compared to tabulated-t of 1.66757 . The calculated-t of this variable was smaller, so it can be inferred that the board of directors had a negative and insignificant impact toward earnings management. Meanwhile, for the audit committee, the t-values resulted from this analysis was -0.368 with 0.715 for significance score and 1.66757 for the tabulatedt. It showed that the audit committee had a negative and insignificant impact toward earnings management.

From the table about the result of regression analysis model II, it can be seen that $\mathrm{t}$-value from the board of directors was 3.615 with 0.001 for significance value. If calculated-t was compared to tabulated-t, the calculated-t score of the board of directors was greater than tabulated-t. So, it can be inferred partially that the board of directors had a positive and significant impact on financial performance. The score for tabulated$t$ used here was 1.66757. The tabulated-t score can be seen from tabulated-t with 68 samples (70-2) and $5 \%(0.05)$ for the percentage. For the audit committee, the score for calculated-t was 1.630 with 0.108 for significance value. If it was compared to 1.66757 of tabulated-t, the calculated-t was smaller so it can be inferred that the audit committee had a positive but insignificant impact toward financial performance. For the variable of earnings management, the calculated-t score was 0.009 with 0.993 for significance value. If it was compared to tabulated-t, the calculated-t score was smaller, so it can be 
inferred that earnings management had a positive but insignificant impact toward the financial performance.

\subsubsection{Sobel test}

Sobel test was used in conducting hypothesis testing for mediation effects. The Sobel test was done by testing the strength of indirect influence of independent variable toward dependent variable through mediator variable. From the Sobel test that had been done, the calculated-t score was -0.3086 that was smaller than tabulated-t score, i.e. 1.66757 with 0.05 of significance level. It shows that the mediator coefficient was not significant and it meant that there was no mediator impact. Therefore, it can be inferred that earnings management did not mediate the relationship between the board of directors and financial performance.

The calculated-t score for audit committee resulted from Sobel test was -0.05583 . It was smaller than the tabulated-t score that was 1.66757 with 0.05 for significance level. It meant that the mediator coefficient was not significant and it had a meaning that there was no mediator impact. Therefore, it can be inferred that earnings management did not mediate the relationship between the audit committee and the financial performance.

\section{Discussion}

The result of regression analysis shows that the variable of the board of directors has a positive and significant impact towards the financial performance. So, the first hypothesis stated that the board of directors has a positive and significant impact towards the financial performance can be accepted. This research supports the previous research done by [2] that shows the positive and significant impact of the board of directors towards the financial performance. This research finding contradicts the research by [1] that shows the insignificant impact of the board of directors towards the financial performance. The more board of directors in a company is, the better financial performance is. In addition, the board of directors has an authority in determining the policy that will be taken by the company both the short-term period and the long-term period.

The audit committee has a positive and insignificant impact towards the financial performance. So, the hypothesis which stated that audit committee has a positive but insignificant impact towards the financial performance can be accepted. This research finding supports the research done by [1] which finds that the audit committee has a positive but insignificant impact towards the financial performance. who reveals that the 
audit committee has a positive and significant impact towards the financial performance. By the existence of audit committee in a company, the financial report of the company is expected to be more qualified by regarding the responsibility and the duties of the audit committee. However, from the hypotheses above, it can be concluded that the amount of audit committee in a company cannot guarantee the effectiveness of audit committee performance in executing their tasks and responsibilities towards the financial performance of the company [1].

The board of directors has a negative and insignificant impact towards earnings management. The third hypothesis which stated that the board of directors has a positive and significant impact towards earnings management is rejected. This research finding is different from the previous research by [8] which finds that the board of directors has a positive and significant impact towards earnings management. This insignificant impact shows that the amount of the board of directors in a company cannot guarantee the decrease in earnings management actions in the company. It happens since the board of directors does not execute the function of supervision towards the earnings management practices and this supervision function is done only by the independent board of commissioners and the audit committee.

The audit committee has a negative and insignificant impact towards the financial performance of the company. So, the hypothesis which stated that audit committee has a negative impact towards earnings management is accepted. This finding is appropriate to the research by [12] that reveals that audit committee has a negative impact towards earnings management. This finding is reinforced by [11] who finds out that the impact of audit committee towards earnings management is not significant. Since it does not have a significant impact, the audit committee has no impact towards earnings management. It can be seen from the regulation of Capital Market Supervisory Agency (Bapepam) that states that the audit committee formation in a company is only done for fulfilling the government stipulation. This statement is also addressed to the assigned members of audit committee who have inappropriate competence and capability that will result in non-optimal and ineffective performance.

Earnings management has a positive but insignificant impact towards the financial performance. So, the fifth hypothesis is rejected. This research is relevant to the research by [13] which shows that earnings management gives positive but insignificant impact towards the financial performance. It is reinforced by a research by [11] which reveals that earnings management has no significant impact towards the financial performance.

From the Sobel test had been done, it can be seen that the mediator impact has no significant impact which means that it has no mediating relationship. In this case, 
earnings management does not mediate the relationship between the board of directors and the financial performance. So, the sixth hypothesis is rejected.

The mediator impact on the audit committee is not significant. It means that earnings management does not mediate the relationship between the audit committee and financial performance. Theoretically, the function of supervision and controlling done by the audit committee towards earnings management has a positive relationship. It can be seen by the decrease in manager's pressure towards the audit committee in compiling the financial report. A research by [14] about testing the direct impact of each variable shows that the audit committee has a positive but insignificant impact towards earnings management and earnings management has a negative and insignificant impact towards financial performance.

\section{Conclusion}

From the result of hypothesis thesis that has been done about the impact of the board of directors and the audit committee towards the financial performance mediated by (intervening variable) earnings management, it can be concluded that: The board of directors has positive and significant impact towards financial performance; The audit committee has a positive but insignificant impact towards financial performance; The board of directors has a negative and insignificant impact towards earnings management; The audit committee has a negative and insignificant impact towards earnings management; Earnings management has a positive but insignificant impact towards financial performance and earnings management does not mediate the relationship between the board of directors and financial performance; and earnings management does not mediate the relationship between the audit committee and financial performance.

\section{Acknowledgements}

By completing this research, the writer has received some help and moral and spiritual motivation. Therefore, the writer wants to express the gratitude to the College of Economic Studies of KBP Padang that has appreciated the writer in accomplishing this research. 


\section{References}

[1] M. F. Widyati, "Pengaruh Dewan Direksi, Komisaris Independen, Komite Audit, Kepemilikan Institusional Terhadap Kinerja Keuangan," J. IImu Manaj., vol. 1, no. 1, pp. 234-249, 2013.

[2] Aminar Sutra Dewi, "Pengaruh Corporate Governance Dan Leverage Terhadap Kinerja Keuangan Pada Perbankan yang Terdaftra Di BEI," J. Kaji. Akunt. Dan Audit., vol. 7, no. 1, pp. 61-71, 2012.

[3] I. S. Exchange, "PENGARUH MEKANISME GOOD CORPORATE GOVERNANCE, INDEPENDENSI AUDITOR, KUALITAS AUDIT DAN FAKTOR LAINNYA TERHADAP MANAJEMEN LABA," vol. 12, no. 1, pp. 53-68, 2010.

[4] A. Ujiyantho and A. Bambang, Ujiyantho, A., \& Bambang, A. (2007). Mekanisme Corporate Governance, Manajemen Laba, dan Kinerja Keuangan, (6), 1-26. 2011.

[5] B. Setiawan, "Pengaruh Independensi, Kualitas Audit Dan Mekanisme Corporate Governance Terhadap Integritas Laporan Keuangan Perusahaan Manufaktur Di Bursa Efek Indonesia," vol. 2, no. 2, pp. 1-15, 2015.

[6] Y. W. N. Ingrid Charistiani, "Pengaruh Kualitas Audit Terhadap Manajemen Laba," J. Akunt. Dan Keuang., vol. 16, no. 1, pp. 52-62, 2014.

[7] A. S. Dewi, D. Sari, and H. Abaharis, "Pengaruh Karakteristik Dewan Komisaris Terhadap Kinerja Perusahaan Manufaktur Di Bursa Efek Indonesia," J. Benefita, vol. 3, no. 3, pp. 1-10, 2018.

[8] S. Iqbal and N. Fachriyah, "Corporate Governance sebagai ALat Pereda Praktik Manajemen Laba (Earning Management)," TEMA, 2016.

[9] N. Septiana, "PENGARUH MEKANISME GOOD CORPORATE GOVERNANCE TERHADAP PROFITABILITAS PERUSAHAAN (Studi pada Perusahaan Makanan dan Minuman Tahun 2011-2014)," vol. 38, no. 2, 2014.

[10] R. Husni, "Pengaruh Mekanisme Good Corporate Governance, Leverage dan Profitabilitas terhadap Manajemen Laba," pp. 2008-2011, 2010.

[11] D. Agustia, F. Ekonomi, B. Universitas, and A. Surabaya, "Pengaruh Faktor Good Corporate Governance, Free Cash Flow, dan Leverage Terhadap Manajemen Laba," vol. 15, no. 1, pp. 27-42, 2013.

[12] J. Ilmu and R. Akuntansi, "KINERJA KEUANGAN Rachma Djazilah Kurnia Sekolah Tinggi IImu Ekonomi Indonesia (STIESIA) Surabaya," J. IImu Dan Ris. Akunt., vol. 5, no. 10, pp. 1-19, 2016.

[13] I. Dan, L. Terhadap, K. Keuangan, and E. Elisetiawati, "April 2016, volume 17 nomor 1," vol. 17, no. April, pp. 17-28, 2016. 
[14] H. D. Perdana, R. P. Putra, S. Murni, and U. S. Maret, "Corporate governance dan kinerja keuangan perusahaan," vol. 4, no. 1, 2016. 